\title{
CORPORATE SOCIAL RESPONSIBILITY REPORTING AND VALUE RELEVANCE OF THE BANKING SECTOR IN BANGLADESH
}

\author{
MASHIUR RAHMAN*, SITI ZALEHA ABDUL RASID AND ROHAIDA BASIRUDDIN \\ Level 10, Menara Razak, Universiti Teknologi Malaysia Kuala Lumpur, Jalan Sultan Yahya Petra (Jalan Semarak), 54100 \\ Kuala Lumpur, Malaysia.
}

*Corresponding author: mashiur1953@gmail.com

Submitted final draft: 18 January 2020 Accepted: 3 February 2020

http://doi.org/10.46754/jssm.2020.07.016

\begin{abstract}
Using a sample of listed Bangladeshi banking companies for the period 20092017, this study investigated whether these banks which disclosed superior CSR information are more valued by the investors. CSR reports can also affect market value of equity because the sustainability report may be observed by the market participants to be a basis of supplementary and corresponding evidence along with the customary valuerelevant accounting variables. Finally, this study also analyses whether CSR disclosure by Islamic banks operating in banking industries is considered in a different way by investors than CSR disclosure by conventional banks. By using a modified Ohlson model, it is evident that CSR disclosure does have noteworthy positive influence on stock prices. Furthermore, CSR disclosure by Islamic banks is associated with higher market valuations than CSR disclosure by conventional banks. The reason behind the fact is that higher CSR information assists market participants to access the inherent risk associated to potential legal action and impending obligations, by this means sinking information asymmetries and the threat of adverse selection.
\end{abstract}

Keywords: Corporate social responsibility reporting, sustainability, value relevance.

\section{Introduction}

Sustainability or CSR reporting (CSRR) may lead to the formation of business value. Value Relevance (VR) examines relationships between economic data (Lo \& Lys, 2000; Byun $\&$ Oh, 2018) with the modified Ohlson (1995) valuation showing additional non-financial data, share value, or stock return (Kothari \& Zimmerman, 1995; de Klerk \& de Villiers, 2012; Gasperini \& Doni, 2015; Houqe et al., 2019). CSRR is a type of non-financial related data. If CSRR is connected to organisation share value, disclosed evidence may be essential to how shareholders value organisations (Hassel et al., 2005; Cormier, 2012). As indicated by Nekhili et al. (2017), specialists can understand from value-relevance tests whether premium data (sustainability or CSRR in this study) is related to the data set that financial specialists use to value organisation stocks.

Previous studies described that accounting figures alone cannot clarify organisation share price, suggesting the significance of nonfinancial data (Comier \& Magnan, 1997), ethical obligations (Choi \& Pae, 2011; Almahrog et al., 2017), and voluntary disclosure (Lapointe- Antunes et al., 2006; Clarkson et al., 2008; Sobhani et al., 2012; Ullah et al., 2015). For a corporation, it is not sufficient to only embrace CSR values, making it essential to report to stakeholders a business's promise to use CSR (Adrian, et al., 2015). Corporate Social Responsibility Reports (CSRR), through which a corporation demonstrates its commitment to CSR, is perhaps the most important and comprehensive CSR document (Barth \& McNichols, 1994). They also demonstrated that the information revealed in CSRR, accompanied by the data stated in yearly reports, delivers superior disclosure regarding the real situation of a corporation to stakeholders. CSRR involves mainly voluntary disclosure, making evident a clear business case for its use (Gray, 2005). As companies will not embrace CSRR unless they benefit from it, this disclosure plays a significant part in investor judgements to trade, purchase, or hold share and equity instruments 

in a corporation by delivering typically nonfinancial information to stakeholders (Beisland, 2009; Dhaliwal et al., 2011).

Thus, considering financial information and non-financial information (CSR) together may elucidate market estimates better than a particular emphasis on financial data (Reverte, 2016). Also, the distribution of supplementary information provides superior reassurance and self-reliance to commercial investors concerning different phases of their operations, growing visibility and decreasing the amount of secretive information (Martínez-Ferrero et al., 2015). Subsequently, these activities could affect the economic value creation of a firm (Figge \& Hahn, 2012). Therefore, it is crucial to investigate whether non-financial information, specifically CSR information, that is disclosed by companies in their annual report or other standalone reports (such as sustainability or CSR reports) is value relevant or not. Consequently, the goal of this study was to understand if providing detailed disclosure on these issues can produce clear benefits in terms of value creation over medium-long time frames.

Multiple sources inspired this study's decision to centre its examination on the banking sector. First, it is evident that banks make superior CSR commitments every year (Viganò \& Nicolai, 2009). However, prior studies suggest that it is vital to examine whether the endeavours made by banks to fulfil their CSR promises are appreciated (Carnevale et al., 2014). Second, to survive in a competitive market, it is vital that banks consider reputational risks (Duellman et al., 2015) because banks are more vulnerable than other corporations to threats to their reputation. Banks run on client trust and a fiduciary relationship exists between the client and bank. From a theoretical point of view, banks may gain an enhanced reputation by performing CSR activities that minimise various market risks (Kim et al., 2012). For the financial industry, previous studies focused on conventional or Shariah-compliant financial firms separately without considering the overall banking sector. Therefore, this study examines the value relevance of CSR evidence on the banking sector.

For the purpose of this study, we investigated the relation between CSR disclosures and value relevance proxies by share price in Bangladeshi listed banking companies during the period 2009 to 2017. Hypotheses were formulated on the relationship between CSRR and value relevance.

The result of the hypothesis testing indicated that CSRR had a significant positive relationship with value relevance measured by Ohlson price model (1995). The finding also showed that the Shariah- based banks disclosing extensive CSR activities are more value relevant comparatively than their conventional counterpart. This is consistent with the notion that Shariah-compliant firms behave ethically and such disclosures create value for investors in the capital markets.

Our study makes a number of important contributions to the existing literature. First, we provide evidence that managers of Bangladeshi firms that used CSR disclosures are more value relevant in the money market. Second, although various regulatory authorities have established frameworks and strategies for sustainability disclosure in the financial sector, such as Global Reporting Initiatives (GRI), very little focus has been given to examining the nature and extent of CSR disclosure based on international guidelines, particularly in a developing country. Third, this study enhances the literature on CSR revelations by constructing a comprehensive disclosure index (methodological contribution) using GRI guidelines and prior research on CSR in banking sector, which has typically been concerned with CSR strategy, CSR policy, and sustainability performance in non-financial sectors. This study also compares the value relevance of the Shariah-compliant firms with conventional firms to observe the perceptions of the market participants. Thus, the following research questions are proposed.

RQ1: What is the relationship between CSR reporting and value relevance in the banking sector of Bangladesh? 
RQ2: Do investors provide more value to the CSR-oriented Islamic banks than conventional banks?

The worldwide movement for socially responsible investment reveals that traditional economic, environmental, and social information is used to make investment choices (Reverte et al., 2016). The approach organisations can adopt to incorporate social, economic, and ecological apprehensions in transparent and responsible manner into their policy, ethics, decision making, and manoeuvres is known as CSR. Over the last two decades, organisations have disclosed more CSR or sustainability information due to increased public interest in social and environmental issues, which been given intensive consideration in mass media (Gray et al., 1995). Several prior studies have examined the effect of financial information on business valuation which can be inflated by market perceptions of data uniformity (Whelan \& McNamara, 2004). Thus, the disclosure of CSR information along with financial information play a vital role in stakeholder investment judgments (Cormier \& Magnan, 2007; Dhaliwal et al. 2011) and begs the question if such revelations create value for investors in capital markets.

Miller \& Modigliani (1966) focused on pioneer research in the area of value relevance, though these researchers did not mention the term value relevance. They are identifying the determinants that influence the returns and the market value of equity. Miller et al. (1966) also worked to improve practical approaches for assuming the cost of capital pertinent to ideal portfolio decisions from statistics on the share price. Ball et al. (1968) also investigated the relationships between stock returns and accounting earnings but did not mention the term "value relevance."

Nonetheless, Amir et al. (1993) were the first to use the term "value relevance extensively" for outlining the association between equity market values and accounting data in terms of the market to book value of equity ratio (Barth et al., 2001; Vafaei et al., 2011). Furthermore, Barth et al. (2001) defined accounting data as value relevant if it has the forecasting capability of the market value of equity. This is consistent with Houqe et al. (2019) who defined the value relevance of earnings as the degree to which accounting earnings summarise information impounded in market prices. Additional reconciliation reveals that a higher quality of earnings better reflects a firm's underlying economics and is, therefore, more value relevant for users of the financial statements (Barth et al., 2001).

In general, previous studies stated that to elucidate an organisation's market value of equity and its deviations, only accounting information is not enough (Saha \& Bose, 2017). Conversely, many academics have encouraged investigation of the value of relevance of nonfinancial information to close the rising gap between the book value and market value of corporate stocks (Barth et al., 1994; Xu et al., 2007) and subsequently the stimulus of nonfinancial variables on the worth of share prices continues to be an exceptionally vital concern in theoretical arguments (Campbell \& Slack, 2008). In this respect, this study was interested in examining the relationship of value relevance of the market value of stocks and non-financial information in terms of CSR disclosure.

For that reason, to assess the relationship between CSR performance or disclosure and market value of stocks, some research has investigated the overall effect of non-financial information in terms of societal, environmentally friendly, and other spaces of business accountability performance or disclosure (de Klerk et al., 2012; Rahman et al., 2019; Rahman et al., 2020). Many previous studies have used the event-study method to investigate the temporary impacts of news concerning social and environmental performance on the organisation's market value of equity (Hashim et al., 2015; Nobanee \& Ellili, 2016). These studies generally conclude that investors/ shareholders penalise businesses for weak performance through adverse abnormal earnings and drops in market estimation. Freedman \& Patten (2004) also advocated that the negative influence of unfavourable ecological enactment 
might be alleviated with more comprehensive reporting. Similarly, Hassel et al. (2005) applied the modified Ohlson (1995) price model, based on companies listed in Stockholm stock exchange, to access the relationship between value relevance in terms of share price and environmental performance ratings. Following the results, social and ecological information regarding performance ratings is value relevant, and reveals that the additional-economic value is a combination of the accounting earnings, the book value of equity and environmental and communal performance.

Furthermore, the study of de Klerk et al. (2012) investigated the stakeholders' view of the supplementary disclosures on sustainability issues and the subsequent effect on their investment decision through applying modified Ohlson model to assess a corporation's equity value. He concluded that the relationship between CSRR and VR is positive; that is, superior sustainability disclosure leads to a higher value of equity. Also, Carnevale et al. (2014) examined the direct effect of sustainability reporting along with the indirect impact of financial information on the corporate share price and whether the VR of CSR or sustainability reports differed across nations. They claimed that investors appreciated the additional evidence regarding sustainability issues that have a positive influence on shares value; however, the indirect effect of book value and earnings per share are negative and insignificant, respectively. They also argued that the VR of the CSR or sustainability information fluctuated through European realms, in line with diverse institutional settings.

In contrast, research conducted by Jones et al. (2007) on Australian companies showed that there is a significant negative relationship between sustainability disclosure and abnormal returns of equity value. Moreover, Cardamone et al. (2012) conducted an investigation based on 178 Italian listed organisations on the Milan Stock Exchange over the period of 2002 - 2008 and claimed a noteworthy adverse association between the company's market worth and CSR revelations, where the market value of share was a function of the earning, book value, and the CSR or sustainability disclosure. They also concluded that book value per share was more relevant for the CSR oriented companies than their counterparts, while the value relevance of earnings per share did not change for these corporations.

Even though the outcomes of empirical research are mixed, many accounting regulators think that information related to economic, social \& environmental dimensions helps investors in policymaking and that such evidence is considered value relevant (Carnevale et al., 2014). Thus, this study hypothesised that CSR revelations reduced the risk of information asymmetries in terms of enhancing business level disclosure, which subsequently impacted the organisation's market value. As a result, this study draws the following hypothesis:

H1: There is a positive relationship between CSR reporting and value relevance in Bangladeshi banking companies.

The banking system whose philosophy is based on Sharia' principles is referred to as the Islamic banking system (Farook et al., 2013). Shariah principles are resultant from the explanation of the Holy Quran (Book contains words of Allah SWT.) and Sunnah (deeds and sayings of Prophet Muhammad). In the Islamic banking system, interest (riba) is strictly prohibited because it creates the opportunity to earn without participating in any losses in the business activities by lending money to others (Hashim et al., 2015). Moreover, trade in speculative deeds (gharar) are also illegal for Islamic banking service as these contracts comprise ambiguous and elusive agreements that are not consistent with Shariah ethics (Zainuldin \& Lui, 2018). But, to compete with other financial institutions, Islamic banks are required to offer products and services that are not only equivalent to conventional banks but also compliant with Shariah rules and regulations. The popular products or Shariahcompliant investments offered under Islamic banking system are Murabaha (purchase then sale through keeping profit margin), Musharaka, 
Mudaraba, Istisna (sales agreement of particular factory-made goods) as well as Ijarah (sale of usufruct). Prior studies classified these products into two categories, Shariah-compliant products and Shariah-based products. Shariah-compliant products speak to the debt-based relationship whereas Shariah-based products are grounded on profit and loss sharing (PLS) principle (Taktak et al., 2010; Zainuldin et al., 2018). Shariah also forms the ethical codes and conduct that deliver direction for accountability and moral behaviour for the Islamic banking system (Lewis, 2001). It shapes Islamic banks into organisations that provide more considerable significance on ethical and moral foundations than conventional banks. Besides, the conventional and Islamic financial systems are different, and the pillar of Islamic economic structure is Shariah principles, in which the primary objectives do not include the capitalising of shareholders' wealth, but incorporate both earnings and communal accountability simultaneously (Alsaadi et al., 2013). Islamic economic system incorporates fiscal and legal traits along with social, spiritual and ethical aspects in terms of principles and the philosophy of Islamic religion, which is relevant to Carroll's (1979) model consistent with the economic, ethical, discretionary and legal classifications (Elasrag, 2015). It is crucial to know that Islamic business bodies exist not only for the wellbeing of benevolent associations, but financially function at an operational and competent means (Alsaadi et al., 2013). However, in maximising stakeholders' wealth, they must also not disregard other moral and social commitments (Mersni et al., 2015) and try to keep the proper balance between returns and social aims and other benefits to their diverse stakeholders concerning Islamic Shariah ideologies (Soedarmono et al., 2017).

In keeping with the above statements, to maintain sustainable monetary growth along with allocating revenue and affluence justifiably and accomplishing social integrity, superior religious, societal and principled duties have been employed upon Shariah-obedient businesses (Zainuldin et al., 2018). Based on the previous arguments, the second hypothesis is stated as follows:

H2: Higher levels of CSR disclosure by Islamic banks are associated with higher share prices relative to CSR disclosure provided by conventional banks.

\section{Theoretical framework}

The theoretical framework of this study is based on stakeholder theory and legitimacy theory. These theories are employed in this study to place theoretical understanding. This research replicated the theoretical understandings of these philosophies and also applied these theories in its research framework. Stakeholder theory elucidates the association between diverse stakeholders and the information they obtain. Executives are employed as the representative of all relevant parties in an organisation; these are the owners and other stakeholders (Yoon et al., 2018). On the other hand, when the value structure of the more extensive social system in which the business operates an object's value structure is consistent, the situation or position of legitimacy that is recognised as an essential element for organisational existence must be present (Byun et al., 2018).

Concerning the intersection between stakeholder theory and legitimacy theory, Deegan (2002, p. 295) specified that "both theories conceptualise the organisation as part of a broader social system". From this point of view of the stakeholder theory, CSR-oriented firms are persuaded to nurture enduring interactions with different stakeholder groups rather than the short-term benefits of the business (Gao \& Zhang, 2015). The elementary conjecture of this theory is that CSR has a positive influence on business financial enactment and it may be a managerial means that helps to efficiently utilize resources (Orlitzky et al., 2003). Financial reporting quality specifies that information delivered to a company's stakeholders is more pertinent for their investment decisions (Norwani et al., 2011; Rahman et al., 2019; Rahman et al., 2020). While legitimacy theory 
discusses the expectations of society in general (as encapsulated within the 'social contract'), stakeholder theory provides a more refined resolution by referring to particular groups within society (stakeholder groups).

As a result, CSR actions and its disclosure deliver operational networks that notify stakeholders of the company's broader wellbeing and its responsibility to act in a communally responsible manner (Baviera-Puig et al., 2015). Despite the fact that disclosures may be driven by communal or sponsor pressure, such revelations are likely to minimise information asymmetries and, therefore, it helps the stockholders to get higher market value of equity (Reverte et al., 2016).

\section{Methodology}

\section{Sample data}

This study examined the relationship between CSR reporting and value relevance. This relationship was tested using quantitative research design. This study was carried out in listed banking companies (conventional \& Islamic) on the Dhaka Stock Exchange (DSE). To gather information based on the research questions, this study limited its investigation to 2017 because this was the most recent year of annual reports available when the analysis began. This study collected annual reports from the DSE library from 2009 to 2017. The starting period of 2009 was chosen because in 2008 the central bank of Bangladesh began to publish CSR reviews for listed commercial banks, which was followed by significant increase in CSR disclosure. Therefore, the data for this study encompassed 270 firm-year observations from 2009 to 2017.

\section{Empirical models}

In line with previous studies (Lourenço et al., 2014; De Klerk et al., 2012; Verbeeten et al., 2016; Reverte et al., 2016), this thesis assesses the previous Ohlson (1995) price model that operationalizes the concept of value relevance:

$$
P_{i t}=\beta_{0}+\beta_{1} B V P S_{i t}+\beta_{2} E P S_{i t}+\beta_{3} C S R R_{i t}+\varepsilon_{i t}
$$

(Model 1)

Where,

Pit = Share price (of common shares) at the end of the quarter;

BVPS = Book value per share at the end of the financial year;

EPS = Earnings per share after the financial year;

CSRR $=$ CSR reporting score/ index over the fiscal year;

$\varepsilon_{\text {it }}=$ An errorterm.

Value relevance research examines the relationship between financial or nonfinancial information and equity market prices. Examining changes in share prices or returns is an alternative method in measuring value relevance where the accurate measurement of the valuation model be subject to the valuation approach undertake (Ohlson, 1995, Barth et al., 2001). Selection of which tactic to embrace be determined equally on the research hypotheses articulated by the research question and on econometric concerns (Landsman et al., 1988). The main difference between value relevance studies investigating price levels and those examining price changes or returns is that the former is concerned in determining what is mirrored in firm value and the latter intended in finding what is redirected in variations in value over time. Thus, if the research question encompasses exploring whether the CSR information is timely, inspecting changes in value is the suitable research approach. This study examines the influence of CSR reporting on the market value of equity, thus price model is more appropriate to justify the research objectives.

Notwithstanding the open deliberation as to which is a better model, this review employs the price-based approach. A few focuses encourage the choice to select the price-based model.First, 
this prototype has been broadly embraced by investors and financial analysts (Carnevale et al., 2014; Verbeeten et al., 2016). Second, previous findings suggest that the estimated slope coefficient of the variable incorporated in the price model is impartial (Reverte et $a l .$, 2016). Third, in this paper, a share price specification of the above model is used so as to moderate the probability of improper inferences based on size variances (the socalled 'scale effect', Buckingham et al. 2011). Barth $\&$ Clinch (2009) found that the un deflated specification (also referred to as the market value of equity specification) of the modified Ohlson (1995) model to be less effective than scaling with number of shares but more effective than scaling with book value, share price, or market value of equity. Besides, Dedman, et al. (2010) also observed the rationality of these prototypes and concluded that simple operational models outperform other more complicated versions which more closely follow Ohlson's theoretical specifications. Therefore, this study employs Ohlson valuation model to justify the impact of CSR reporting on value relevance in terms of market value of equity. This review, along these lines, picks the price model for exploring the relationship between organisations' reasonably estimated worth measured by the market value of equity and the magnitude of CSR reporting.

The second objective of this study is to assess the relationship between earnings management and CSR reporting in the Islamic banking sector. This study introduces an Islamic Dummy as an independent variable to differentiate its impact from conventional banking counterpart in this association. Additionally, EPS and BVPS are considered to test the second research hypothesis (H2).

$$
P_{i t}=\beta 0+\beta_{1} \text { CSRR }_{i t}+\beta_{2} \text { Islamic }_{\text {Dummy }}+\beta_{3} \text { CSRRxIslamic }_{\text {Dummy }}+\beta_{4} E P S+\beta 5 B V P S+\varepsilon i t
$$

Where,

Pit $\quad=$ Share price (of common shares) at the end of the quarter;

BVPS = Book value per share at the end of the financial year;

EPS $=$ Earnings per share after the financial year;

CSRR $=$ CSR reporting score/ index over the fiscal year;

Islamic $_{\text {Dummy }}=$ Islamic Dummy that coded as 1 if the firm Shariah-compliant, 0 otherwise.

$\varepsilon_{\text {it }} \quad=$ An errorterm.

\section{Independent variable - corporate social responsibility reporting indices}

To construct an inclusive magnitude of a bank's commitment to sustainability or CSR reporting, this study considers these issue areas to be more relevant to banks in terms of financial Service Sector (FSS) of GRI and extensive review of prior studies for developing the ten major aspects of CSRR issue areas, namely: Product \& service responsibility, energy consumption and savings, natural environmental issues, community investment, employee development, economic issues, human rights, education, health \& Islamic commitment. Following Haniffa \& Cooke (2005) and Muttakin et al., (2015) the CSRR index is calculated as follows:
Where,

$$
C S R R=\sum_{i=1}^{n} d i
$$

$\mathrm{d}_{\mathrm{i}}=1$ if the item $d i$ is reported;

$\mathrm{d}_{\mathrm{i}}=0$ if the item is not reported;

$n=$ number of items.

To assess the reliability of CSR reporting index, reliable with previous revelation index research (Khan et al., 2009; Muttakin et al., 2015; Belal et al., 2015), this study will apply the Cronbach's coefficient alpha (Cronbach, 1951) to measure the internal consistency and reliability of the CSRR index (Muttakin et al., 2015; Belal et al., 2015). The coefficient alpha for the nine unlike information groups 
under three board classifications of disclosure index is expected to be more than 0.70 . This measurement delivers good backing in the condition where the set of selected items in the disclosure index captures the same fundamental construct (Muttakin et al., 2015). This CSR reporting index is shown in Appendix 1.

\section{Results and Discussion}

Table 1 reports the descriptive statistics of the dependent and independent variables. The table indicates that there is a high variability in CSR disclosure practices across Bangladeshi listed banks, as the total CSR disclosure varies from 0.216 to 0.674 .

Table 2 reports the correlation coefficients among the regressors and it can be seen that the highest percentage of correlations is between Share price and CSRR $(r=0.652)$. Table 3 shows that the Variance Inflation Factors (VIFs) for all correlated variables did not exceed 10, which is the cut-off point recommended by Hair et al. (2010). Therefore, there were no multicollinearity issues in this study. Gujarati \& Porter (2008) stated that when a correlation between an independent variable is less than 0.80 then it is acceptable. This study did not find any correlations between independent variables that exceed the 0.80 limit, which shows an absence of multicollinearity problems.

The regression findings indicate that the main independent variable Corporate Social Responsibility Reporting (CSRR) has a significant and positive impact on share value $(\mathrm{P})$. Thus, higher CSRR indicates a higher share price, suggesting that additional CSR information enhances the market value of equity. Overall, the study results support research hypothesis (H1). The study findings are

Table 1: Descriptive statistics $(N=270)$

\begin{tabular}{lccccccc}
\hline \multicolumn{1}{c}{ Variables } & Mean & Median & $\begin{array}{c}\text { Standard } \\
\text { Deviation }\end{array}$ & Minimum & Maximum & Skewness & Kurtosis \\
\hline$P$ & 22.564 & 22.420 & 17.657 & 4.000 & 122.100 & 0.013 & 0.203 \\
CSRR & 0.479 & 0.470 & 0.105 & 0.216 & 0.674 & -0.182 & 0.534 \\
IslamicDummy & 0.233 & 0.000 & 0.423 & 0.000 & 0.100 & 1.268 & 0.395 \\
BVPS & 23.953 & 23.915 & 14.698 & -15.941 & 97.729 & 0.007 & 0.211 \\
EPS & 2.777 & 2.770 & 2.036 & -2.740 & 15.100 & 0.013 & 1.028 \\
\hline
\end{tabular}

Notes: $C S R R=$ corporate social responsibility reporting; IslamicDummy $=$ as measure of Shariah compliant banks that coded as 1 if the firm Shariah-compliant, 0 otherwise; $P=$ share price; $B V P S=$ book value per share; $E P S=$ earnings per share

Table 2: Pairwise correlation matrix for Price-CSRR Models ( $\mathrm{N}=270)$

\begin{tabular}{|c|c|c|c|c|c|c|c|}
\hline \multicolumn{8}{|c|}{ Correlation } \\
\hline & & 1 & 2 & 3 & 4 & 5 & 6 \\
\hline 1 & PRICE (P) & 1 & .652 & .359 & .652 & 496 & .545 \\
\hline 2 & CSRR & & 1 & .387 & .366 & .237 & -.134 \\
\hline 3 & EPS & & & 1 & .332 & .643 & -.203 \\
\hline 4 & BVPS & & & & 1 & -.126 & .485 \\
\hline 5 & Islamic Dummy & & & & & 1 & -.032 \\
\hline 6 & CSRR *Islamic Dummy & & & & & & 1 \\
\hline
\end{tabular}

Notes: The table shows Pearson correlation coefficients among the main variables involved in the analysis. 
in line with Clarkson et al. (2010), Buckingham et al. (2011), de Klerk et al. (2012), Reverte et al. (2016) and Verbeeten et al. (2016).

In Model 1, the coefficients for EPS and BVPS have a significant and positive relationship with the market value of equity, suggesting that accounting information is value relevant and aids investment decisions. Therefore, investors should give importance to accounting information (Campbell \& Slack, 2008; Reverte et al., 2016). As a whole, these results support the notion that CSR information aids market participant predictions and more value relevant and the result is statistically significant at 5\% level. These outcomes support previous studies (Reverte et al., 2016; Verbeeten et al., 2016).

The adjusted $\mathrm{R}^{2}$ for Model 1 was 0.827 (Table 4), indicating that the model explained $82.7 \%$ of the variance regarding the relationship between CSRR and value relevance for Bangladeshi banks. This result shows higher explanatory power than recent value relevance studies by de Klerk et al. (2012) and Reverte et al. (2016). Thus, CSR disclosure delivers additional value relevant information to market participants in the Bangladeshi banking sector in comparison to the Canadian and Finnish banking sectors.

In Model 2, we explore the impact of CSRR index on the value relevance in Shariahcompliant banks. The coefficients for EPS and BVPS also have a significant and positive relationship with the share price, indicating that accounting information is value relevant and aids investment decisions (Reverte et al., 2016). Moreover, In Model 2, this study analysed the effect of CSRR on VR (proxied by share price) and observed a positive and statistically significant association (coefficient $=-34.115$, $p=0.001)$. The significant positive coefficient indicates that additional CSR information is incrementally evaluated by the market. Islamic Dummy was positive and significant with share price at $p<0.05$. This result suggests that Shariah-compliant firms are value relevant for the market participants. The interaction variable CSRR* Islamic Dummy showed a significant and positive association with share price. This suggests that Shariah-compliant CSR banks are value relevant to the investors. The coefficient of the moderating term was positive (4.341) and significant at a $1 \%$ significance level. The higher standardized coefficient of the interaction term of CSRR*Islamic Dummy on this relationship indicates market participants value more the CSR oriented Islamic banks than their conventional counterparts. This result supports research hypothesis ( $\mathrm{H} 2)$. The adjusted $\mathrm{R}^{2}$ for Model 2 was 0.823 (Table 3 ), indicating that the model explained $82.3 \%$ of the variance regarding the relationship between CSRR and value relevance for Shariah-compliant Bangladeshi banks.

To test for heteroscedasticity, this study used Breusch-Pagan/Cook-Weisberg test. The White test was used for Homoscedasticity (Table: 3). According to these tests, the null hypothesis was accepted due to the insignificant p-value, indicating no heteroscedastic and homoscedastic data. This study used the Kolmogorov-Smirnov and Shapiro-Wilk tests in addition to the skewness and kurtosis tests which were used to check for data normality. These tests tested the null hypothesis to check if data was not normally distributed. According to the test results the null hypothesis was rejected due to the significant $\mathrm{p}$-value, indicating that the data was normally distributed (non- tabulated). Fixed effect estimation was conducted using the Hausman test. The results of the fixed effect estimator were compared with the panel pooled $O L S$ estimator to check for result authenticity. Also, lagged regression was used to check $O L S$ regression result consistency.

Value relevance researches are considered to evaluate whether specific accounting figures, and in the perspective of this research also nonfinancial data, for instance, CSR (followed by Hassel et al., 2005), redirect facts that are considered by stockholders in valuing a corporation's share price (Buckingham et al., 2011). The outcomes of this study by considering the modified Ohlson (1995) price model indicate that CSR information and financial date mutually generate more appropriate market valuations 
Table 3: The result of multivariate regressions

\begin{tabular}{|c|c|c|}
\hline \multicolumn{3}{|c|}{$\begin{array}{l}\text { Model 2: } P=\beta 0+\beta 1 \text { BVPSit }+\beta 2 \text { EPSit }+\beta 3 \text { CSRRit }+\beta 4 \text { Islamic Dummy }+\beta 5 \text { CSRRit } \times \text { Islamic } \\
\text { Dummy }+\varepsilon \text { it }\end{array}$} \\
\hline \multirow{4}{*}{ Variables } & Coefficient (t-statist & \\
\hline & Dependent variable PI & \\
\hline & MODEL 1 & MODEL 2 \\
\hline & Fixed Effect Estimation & Fixed Effect Estimation \\
\hline Intercept & $325.049(0.010)^{* *}$ & $339.858(0.070)^{*}$ \\
\hline CSRR & $35.522(0.021)^{* * *}$ & $34.115(0.002)^{* * *}$ \\
\hline BVPS & $0.113(0.042) * *$ & $0.350(.014)^{* *}$ \\
\hline EPS & $2.826(0.000)^{* *}$ & $2.737(0.000)^{* * * *}$ \\
\hline Islamic Dummy & & $0.607(0.034) * *$ \\
\hline CSRR* Islamic Dummy & & $4.341(0.008)^{* * * *}$ \\
\hline Adj. R2 & 0.827 & 0.823 \\
\hline F-statistics & 4.331 & 6.764 \\
\hline Mean VIF & 1.715 & 1.855 \\
\hline Observations & 270 & 270 \\
\hline
\end{tabular}

Notes: The numerical figures in parentheses are t-values. ${ }^{*}, * * \& * * *$ indicate significance at the $10 \%, 5 \%$

$\& 1 \%$ levels, respectively.

than only accounting data (results support H1). Thus, firms that disclose higher CSR activities are likely to have a greater market value of equity paralleled to other concerns with inferior intensities in CSR reporting. Thus, findings of the current study are according to many previous studies that indicated a significant positive relationship between CSRR and value relevance (Jones et al., 2007; Cardamone et al., 2012; Tafti et al., 2012; Mallin et al., 2014; Hashim et al., 2015; Nobanee et al., 2016).

The banking sector is playing a vital role for the economic prosperity of both Bangladesh and Indonesia. The size of the banking sector relative to gross domestic product (GDP) was 69.96 per cent in 2010 compared to 32.79 percent of the stock market in Bangladesh (Uddin \& Suzuki, 2015). The financial market of both Islamic and non-Islamic countries with a sizeable Muslim community has been associated with the rise of Islamic banking in recent years (Maswadeh, 2015). Even nonMuslims have shown their immense inclination toward Islamic banking as it has already pointed out that around 40 percent of the market share of Islamic banks and conventional banks with Islamic branches or windows constituted of such people (Ariff, 2014). Belal \& Momin (2009) found few disclosures in the Islamic community. However, this research argues that Islamic banking advocates for social contribution and thus should be more involved in CSR activities and disclosures. Previous study also provides evidence that banks complying with Islamic banking should focus more on social activities as per definition of Islamic banking (Anup, 2018). Thus, Islamic banks are expected to have more CSR spending reported to the Bangladesh Bank, other stakeholders \& society. Based on the literature, it was hypothesised that Shariah principles positively moderate the relationship between CSR reporting and value relevance $\left(\mathrm{H}_{2}\right)$. This study finds a significant positive association that indicates Shariah-compliant Bangladeshi banks along with high CSR initiatives are more value relevant to the market participants. 


\section{Sensitivity Analysis}

This study performed robustness checks to confirm that outcomes were robust for substitute conditions. For Bangladeshi listed banks, financial statements are generally disclosed within the first quarter, at the end of the fiscal period, but annual reports are commonly published 3-6 months after the end of the fiscal year. However, CSR reporting is voluntary in Bangladesh and annual reports are a prime source of non-financial information. Thus, this study replaced the share prices at the end of the quarter with share prices at the end of 6 months to confirm that CSR reporting was accessible to stakeholders and justify the consistency of the research findings but it did not find any significant changes in the relationship between CSRR-VR and moderating effects from Shariah (Islamic Banks) on this relationship. The results are shown in Table 4. These outcomes support that the main results in Table 3 were not dissimilar to the price proxy of Value Relevance.

In place of fixed and random effects estimators, this study used other panel data techniques such as pooled $O L S$ regression. This alternative estimator demonstrated outcomes similar to the results of the main study and support the connected research hypotheses $\left(\mathrm{H}_{1}\right.$ and $\left.\mathrm{H}_{2}\right)$ as the main study results were not biased due to other panel estimators such as the Fixed-effect estimator. The results are shown in Table 5.

Table 4: The result of alternative dependent variable proxy

Model 1: $P=\beta 0+\beta 1 B V P S$ it $+\beta 2$ EPS it $+\beta 3$ CSRR it $+\varepsilon$ it

Model 2: $P=\beta 0+\beta 1$ BVPSit $+\beta 2$ EPSit $+\beta 3$ CSRRit $+\beta 4$ Islamic Dummy $+\beta 5$ CSRRit $\times$ Islamic

Dummy $+\varepsilon$ it

\begin{tabular}{|c|c|c|}
\hline Variables & \multicolumn{2}{|c|}{ Coefficient (t-statistics) } \\
\hline \multicolumn{3}{|c|}{ Dependent Variable (PRICE) } \\
\hline & Model 1 & I odel 2 \\
\hline Intercept & $2.063(0.000)^{* * * *}$ & $6.350(0.000)^{* * *}$ \\
\hline CSRR & $3.597(0.019)^{* *}$ & $3.404(0.009)^{* * *}$ \\
\hline BVPS & $2.237(0.020)^{* * *}$ & $0.180(0.025)^{* *}$ \\
\hline EPS & $1.454(0.010)^{* * *}$ & $2.404(0.001)^{* * *}$ \\
\hline Islamic Dummy & & $2.161(0.013)^{* *}$ \\
\hline CSRR*Islamic Dummy & & $4.151(0.009) * * *$ \\
\hline Adjusted $\mathrm{R}^{2}$ & 0.849 & 0.831 \\
\hline F-statistics & $134.849(0.000)$ & $36.706(0.000)$ \\
\hline Obs. (Banks) & 270 & 270 \\
\hline No. of Banks & 30 & 30 \\
\hline Mean VIF & 1.715 & 1.855 \\
\hline
\end{tabular}

Notes: The numerical figures in parentheses are t-values. *, ** and *** indicate significance at the $10 \%, 5 \%$ and $1 \%$ levels, respectively. 
Table 5: Robustness Tests: Alternative Estimation Methods (Pooled Panel OLS instead of FE Estimator)

\begin{tabular}{|c|c|c|}
\hline \multicolumn{3}{|c|}{ Model 1: $P=\beta 0+\beta 1$ BVPS it $+\beta 2$ EPS it $+\beta 3$ CSRR it $+\varepsilon$ it } \\
\hline \multicolumn{3}{|c|}{$\begin{array}{l}\text { Model 2: } P=\beta 0+\beta 1 \text { BVPSit }+\beta 2 \text { EPSit }+\beta 3 \text { CSRRit }+\beta 4 \text { Islamic Dummy }+\beta 5 \text { CSRRit } \times \text { Islamic } \\
\text { Dummy }+\varepsilon \text { it }\end{array}$} \\
\hline \multirow{2}{*}{$\begin{array}{l}\text { Variables } \\
\text { Dependent Variable (PRICE) }\end{array}$} & \multicolumn{2}{|c|}{ Coefficient (t-statistics) } \\
\hline & $\begin{array}{c}\text { MODEL } 1 \\
\text { Pooled OLS Estimation }\end{array}$ & $\begin{array}{c}\text { MODEL } 2 \\
\text { Pooled OLS Estimation }\end{array}$ \\
\hline Intercept & $7.293(0.000)^{* * *}$ & $8.849(0.009)^{* * *}$ \\
\hline CSRR & $5.336(0.013)^{* *}$ & $4.681(0.000) * * *$ \\
\hline BVPS & $0.358(0.022) * *$ & $0.193(0.005)^{* * *}$ \\
\hline EPS & $2.706(0.031) * *$ & $1.946(0.000) * * *$ \\
\hline Islamic Dummy & & $95.174(0.000)^{* * *}$ \\
\hline CSRR* Islamic Dummy & & $1.078(0.037)^{* *}$ \\
\hline Adj. R2 & 0.847 & 0.852 \\
\hline F-statistics & $243.532(0.000)$ & $105.964(0.000)$ \\
\hline Mean VIF & 1.715 & 1.855 \\
\hline Observations & 270 & 270 \\
\hline No. of Banks & 30 & 30 \\
\hline
\end{tabular}

Notes: The numerical figures in parentheses are t-values. $* * *$ and $* * *$ indicate significance at the $10 \%$, $5 \%$ and $1 \%$ levels, respectively.

Source: Author's calculation

\section{Conclusion}

This study examined the impact of corporate social responsibility reporting on value relevance for listed financial firms in Bangladesh for the period from 2009 to 2017. The study specified, examined, and achieved two main objectives. The first objective was to investigate the impact of CSRR on value relevance using a researcher constructed CSR disclosure index, while the second objective was to examine the moderating effect of Shariah principles on the same model. The findings of the study for the first objective revealed that high CSR disclosure firms have higher market value in terms of share price, compared to firms which have poor reporting of CSR information. Similarly, the findings for objective two also revealed that Bangladeshi listed financial firms that follow Shariah principles are more value relevant then their conventional counterpart and at the same time they also generate more disclosure of CSR initiatives.

This study has several contributions and practical implications. At the outset, this study is the first rigorous and comprehensive study to examine the impact of CSRR on value relevance in the Bangladeshi banking sector and the first study, as per the researcher's knowledge, to construct a comprehensive CSRR index. Moreover, the study has also provided novel contributions and extensions to the existing CSR reporting literature. To the best of the author's knowledge, there is a shortage of studies that have examined the connection between the CSR reporting and value relevance with the Shariah principles as a moderator. Concerning the practical implications of the study, the findings of the study are expected to be used by corporations to achieve apparent reporting performance and maximise the market value 
of equity. Regulators can also use the findings of the study to issue rules and regulations that have an impact on enhancing social initiatives and firm performance in terms of the share price. The study has some limitations that could be considered as avenues for future research. This research is aware that other regulations and standards have been developed concerning sustainability matters by several associations, in addition to the GRI guidelines. Thus, the hypothesis that developed in this study could be considered in future research for different global guidelines based on sustainability issues such as UN global compact, WRI, ISO, and CDP, etc. Finally, future research could investigate the impact of CSR disclosures on different stakeholder attitudes (such as employee motivation or customer satisfaction). Considering only the share price implications might not be sufficient to understand the mechanisms through which CSR disclosures could affect future financial performance.

\section{Acknowledgements}

The authors wish to thank the reviewers for their valuable comments and the University providing the facilities for the research to be carried out.

\section{References}

Adrian, M., Warren, M., \& Chris, C. (2015). Value relevance and corporate responsibility reporting in the South African context: an alternate view post king-III. South African Journal of Economic and Management Sciences, 18(4), 500-518.

Almahrog, Y., Ali-Aribi, Z., \& Arun, T. (2017). Earnings management and corporate social responsibility: UK evidence. Journal of Financial Reporting and Accounting, 16(2), 311- 332. doi.org/10.1108/JFRA-11-20160092.

Alsaadi, Abdullah; Jaafar, Azis, \& Ebrahim, M. S. (2013). Corporate social responsibility, Shariah-compliant and earnings management. Seventh Asia Pacific
Interdisciplinary Research in Accounting Conference, 44, 1-48.

Amir, E., Harris, T. S., \& Venuti, E. K. (1993). A comparison of the value-relevance of U.S. Versus Non-U.S. GAAP accounting measures using form 20-F Reconciliations. Journal of Accounting Research, 31, 230264. doi:10.2307/2491172.

Ariff, M. (2014). Whither Islamic banking. The World Economy, 37(6), 733-746.

Ball, R., \& Brown, P., (1968). An empirical evaluation of accounting income numbers. Journal of Accounting Research, 6(2), 159178.

Barth, M., Beaver, W.H., \& Landsman, W.

R. (2001). The relevance of the value relevance literature for financial accounting standard setting: Another view. Journal of Accounting Economic, 31,77- 104.

Barth, M.E., \& Clinch, G. (2009). Scale effects in capital markets-based accounting research. Journal of Business Finance and Accounting, 36 (3\&4),253-288.

Barth, M. E., \& McNichols, M. F. (1994). Estimation and market valuation of environmental liabilities relating to superfund sites. Journal of Accounting Research, 32(3), 177-209.

Baviera-Puig, A., Gómez-Navarro, T., GarcíaMelón, M., \& García-Martínez, G. (2015). Assessing the communication quality of CSR reports. A case study on four Spanish food companies. Sustainability, 7, 1101011031.

Beisland, L. (2009). A review of the value relevance literature. The Open Business Journal, 2, 7- 27.

Belal, A. R., \& Abdelsalam, O. H. (2015). Ethical reporting in Islamic bank Bangladesh limited (1983-2010). Journal of Business Ethics, 129, 769-784. doi:10.1007/s10551014-2133-8.

Belal, A.R., \& Momin, M. (2009). Corporate social reporting (CSR) in emerging 
economies: a review and future direction. Accounting in Emerging Economies, 9, 119-143.

Botosan, C.A. (1997). Disclosure level and the cost of equity capital. The Accounting Review, 72(3), 323-350.

Buckingham, G., Gregory, A., \& Whittaker, J. M. (2011). Do markets value corporate social responsibility in the United Kingdom? SSRN. doi.org/10.2139/ssrn.1978921.

Byun, S. K., \& Oh, J. (2018). Local corporate social responsibility, media coverage, and shareholder value. Journal of Banking and Finance, 87, 68-86.

Campbell, D. J., \& Slack, R. E. (2008). Narrative reporting: Analysts' perceptions of its value and relevance, ACCA, Research Report 104, London.

Cardamone, P., Carnevale, C. \& Giunta, F. (2012). The value relevance of social report: evidence from listed Italian companies. Journal of Applied Accounting Research, 13(3), 255-269.

Carnevale, C., \& Mazzuca, M. (2014). Sustainability report and bank valuation: evidence from European stock markets. Business Ethics: A European Review, 23(1), 69-90.

Carroll, A. B. (1979). A three-dimensional conceptual model of corporate performance. Academy of Management Review, 4(4), 497-505.

Choi, T. H., \& Pae, J. (2011). Business ethics and financial reporting quality: Evidence from Korea. Journal of Business Ethics, 103(3), 403-427.

Clarkson, P. M., Li, Y., Richardson, G. D., \& Vasvari, F. P. (2008). Revisiting the relation between environmental performance and environmental disclosure: An empirical analysis. Accounting, Organizations and Society, 33(4-5), 303-327.

Clarkson, P., Fang, X., Li, Y., \& Gordon, R. (2010). The relevance of environmental disclosures for investors \& other stakeholder groups: Are such disclosures incrementally informative? Journal of Accounting and Public Policy, 32(5), 410-431.

Cormier, D. (2012). On the relevance of social and environmental disclosures and corporate governance for financial analyst's forecasts: Canadian evidence. Cahier de Recherche, 3000, 1-44.

Cormier, D., \& Magnan, M. (1997). Investors' assessment of implicit environmental liabilities: An empirical investigation. Journal of Accounting and Public Policy, 16(2), 215-241.

Cronbach, L.J. (1951). Coefficient alpha \& the internal structure of tests. Psychometrika, 16(3), 297-334.

De Klerk, M., \& de Villiers, C. (2012). The value relevance of corporate responsibility reporting: South African evidence. Meditari Accountancy Research, 20(1), 21-38.

Dedman, E. T. Kungwal \& Stark, A. W. (2010). Dividend displacement, market value, regular and special dividends, and share buybacks in the UK. SSRN Working paper no. 1574770 .

Deegan, C. (2002). The legitimising effect of social \& environmental disclosures: a theoretical foundation. Account Audit Account Journal, 15(3), 282-311.

Dhaliwal, D. S., Li, O. Z., Tsang, A., \& Yang, Y. G. (2011). Voluntary nonfinancial disclosure $\&$ the cost of equity capital: The initiation of corporate social responsibility reporting. The Accounting Review, 86(1), 59-100.

Duellman, S., Hurwitz, H., \& Sun, Y. (2015). Managerial overconfidence and audit fees. Journal of Contemporary Accounting and Economics, 11(2), 148-165.

Elasrag, H. (2015). Corporate Social Responsibility: An Islamic Perspective. Munich Personal RePEc Archive MPRA 5. 
Farook, S., Hassan, M. K., \& Clinch, G. (2013). Pacific-basin Finance Journal Islamic bank incentives and discretionary loan loss provisions. Pacific-Basin Finance Journal, 28, 152- 174.

Figge, F., \& Hahn, T. (2012). Is green and profitable sustainable? Assessing the tradeoff between economic and environmental aspects. International Journal of Production Economics, 140(1), 92-102.

Freedman, M., \& Patten, D. M. (2004). Evidence on a pernicious effect on financial report environmental disclosure. Accounting Forum, 28(1), 27-41.

Gao, L., \& Zhang, J. H. (2015). Firms' earnings smoothing, corporate social responsibility, and valuation. Journal of Corporate Finance, 32, 108-127.

Gasperini, A., \& Doni, F. (2015). Sustainability reporting and value relevance: Empirical evidence from the beverage industry. 10th International Forum on Knowledge Asset Dynamics (IFKAD), 551-566.

Gray, R. (2005). Taking a long view on what we now know about social and environmental accountability and reporting. Electronic Journal of Radical Organisation Theory, 9, $1-31$.

Gray, R., Kouhy, R., \& Lavers, S. (1995). Methodological themes: constructing a research database of social and environmental reporting by UK companies. Accounting, Auditing and Accountability Journal, 8, 78-101.

GRI (2013). G4 Sustainability Reporting Guidelines - Implementation Manual. Retrieved from Respect International website: http://www.respect.international/ g4-sustainability-reporting-guidelinesimplementation-manual/

Gujarati D. N. \& Porter D. C. (2008). Basic Econometrics (5th edition) New York. McGraw-Hill.

Gul, F. A., \& Leung, S. (2004). Board leadership, outside directors' expertise and voluntary corporate disclosure. Journal of Accounting and Public Policy, 23(5), 351-379.

Haniffa, R. M., \& Cooke, T. E. (2005). The impact of culture and governance on corporate social reporting. Journal of Accounting and Public Policy, 24(5), 391430.

Haniffa, R.M., and Hudaib, M. (2007). Exploring the ethical identity of Islamic banks via communication in annual reports. Journal of Business Ethics, 76 (1), 97-116.

Hashim, F., Darina, N., \& Amran, A. (2015). Corporate governance and sustainability practices in Islamic financial institutions: The role of country of origin. Procedia Economics and Finance, 31(15), 36-43.

Hassel, L., Nilsson, H., \& Nyquist, S. (2005). The value relevance of environmental performance, European Accounting Review, 14, 41-61.

Houqe, M., Zijl, T. Van, Karim, A. K. M. W., $\&$ St, T. (2019). The value relevance of corporate donations. Pacific-Basin Finance Journal, e101127.https://doi.org/10.1016/j. pacfin.2019.03.004.

Jones, S., Frost, G., Loftus, J., \& Van Der, L.

S. (2007). An empirical examination of the market returns and financial performance of entities engaged in sustainability reporting. Australia Account Review 17(1), 78-87.

Khan, H. (2010). The effect of corporate governance elements on corporate social responsibility (CSR) reporting. International Journal of Law and Management, 52(2), 82-109.

Khan, H. U. Z., Halabi, A. K., \& Samy, M. (2009). Corporate social responsibility (CSR) reporting: a study of selected banking companies in Bangladesh. Social Responsibility Journal, 5(3), 344-357.

Kim, Y., Park, M. S., \& Wier, B. (2012). Is earnings quality associated with corporate social responsibility? The Accounting Review, 87(3), 761-796. 
Kothari, S. P., \& Zimmerman, J. L. (1995). Price and return models. Journal of Accounting Economic. 20(2), 155- 192.

Landsman, W. R., Miller, B. L. \& Yeh, S. (2007). Implications of components of income excluded from pro forma earnings for future profitability and equity valuation. Journal of Business Finance and Accounting, 34,(3 \& 4), 650-675.

Lapointe Antunes, P., Cormier, D., Magnan, M., \& Gay Angers, S. (2006). On the relationship between voluntary disclosure, earnings smoothing and the value relevance of earnings: The case of Switzerland. European Accounting Review, 15(4), 465505.

Lewis, S. (2001). Measuring corporate reputation. Corporate Communications: An International Journal, 6(1), 31-35. doi:10.1108/13563280110381198.

Lo, K., \& Lys, T. (2000). The Ohlson Model: Contribution to valuation theory, limitations, and empirical applications. Journal of Accounting, Auditing and Finance, 15(3), 337-367.

Lourenço, I.C., Branco, M.C., \& Curto, J.D. (2012). How Does the Market Value Corporate Sustainability Performance? Journal of Business Ethics, 108(4), 417428.

Mallin, C., Farag, H., and Ow-yong, K. (2014). Corporate social responsibility and financial performance in Islamic banks. Journal of Economic Behaviour and Organization, 103, 21-38.

Martínez-Ferrero, J., Gallego-Álvarez, I., \& García-Sánchez, I. M. (2015).Abidirectional analysis of earnings management and corporate social responsibility: the moderating effect of stakeholder \& investor protection. Australian Accounting Review, 25(4), 359- 371.

Mersni, H., \& Othman, H. B. (2015). The impact of corporate governance mechanisms on earnings management in Islamic banks in the Middle East region. Journal of Islamic Accounting and Business Research, 7(4), 318-348.

Miller, M. H, Modigliani, F. (1966). Some estimates of the cost of capital to the electric utility industry, 1954-1957. The American Economic Review, 56(3), 333-391.

Muttakin, M. B., Khan, A., \& Azim, M. I. (2015). Corporate social responsibility disclosures and earnings quality. Managerial Auditing Journal, 30(3), 277-298.

Nekhili, M., Nagati, H., Chtioui, T., \& Rebolledo, C. (2017). Corporate social responsibility disclosure and market value: Family versus nonfamily fi rms. Journal of Business Research, 77, 41-52.

Nobanee, H., \& Ellili, N. (2016). Corporate sustainability disclosure in annual reports: Evidence from UAE banks : Islamic versus conventional. Renewable and Sustainable Energy Reviews, 55, 1336-1341. doi. org/10.1016/j.rser.2015.07.084.

Norwani, N. M., Mohamad, Z. Z., \& Chek, I. T. (2011). Corporate governance failure and its impact on financial reporting within selected companies. International Journal of Business and Social Science, 2(21),205213.

Ohlson, J, (1995). Earnings, book values, and dividends in equity valuation. Contemporary Accounting Research, 11(2), 661-687.

Orlitzky, M., Schmidt, F.L., \& Rynes, S. L. (2003). Corporate social and financial performance: a meta-analysis. Organization Studies, 24, 403-441.

Rahman, M., \& Chowdhury, S. (2020). Relationship Between Corporate Social Responsibility and Earnings Management: A Systematic Review of Measurement Methods. International Journal of Trend in Scientific Research and Development, 4(2), 389-397.

Rahman, M., \& Chowdhury, S. (2019). Sustainability Reporting and Firm Financial 
Performance: A Review of Measurement Tactics. International Journal of Engineering Development and Research (IJEDR), 7(4), 723-730.

Reverte, C. (2016). Corporate social responsibility disclosure and market valuation: Evidence from Spanish listed firms. Review of Managerial Science, 10(2), 411-435.

Saha, A. K. (2018). Relationship between corporate social responsibility performance and disclosures: Commercial banks of Bangladesh. Social Responsibility Journal, 15(4), 451-468. doi.org/10.1108/SRJ-072017-0137

Saha, A., \& Bose, S. (2017). The value relevance of financial and non-financial information: evidence from recent academic literature. Advances in Finance, Accounting and Economics, 220-243. doi.org/10.4018/9781-5225-1900-3.ch015

Sobhani, F. A., Amran, A., and Zainuddin, Y. (2012). Sustainability disclosure in annual reports and websites: a study of the banking industry in Bangladesh. Journal of Cleaner Production, 23(1), 75-85.

Tafti, S. F., Hosseini, S. F., and Emami, S. A. (2012). Assessment the corporate social responsibility according to islamic values: A case study of Sarmayeh bank. ProcediaSocial and Behavioural Sciences, 58, 11391148.

Ullah, M. H., and Rahman, M. A. (2015). Corporate social responsibility reporting practices in banking companies in Bangladesh. Journal of Financial
Reporting and Accounting, 13(2), 200-225. doi:10.1108/jfra-05-2013-0038

Vafaei, A., Taylor, D., \& Ahmed, K. (2011). The value relevance of intellectual capital disclosures. Journal of Intellectual Capital, 12(3), 407-429.

Verbeeten, F. H. M., Gamerschlag, R., \& Möller, K. (2016). Are CSR disclosures relevant for investors? Empirical evidence from Germany. Management Decision, 54(6), $1359-1382$.

Viganò, F., \& Nicolai, D. (2009). CSR in the European banking sector: evidence from a sector survey. Corporate Social Responsibility in Europe, Barth, R. \& Wolff, F. (Eds.) London: Edward Elgar.

Whelan, C., \& McNamara, R. (2004). The impact of earnings management on the value relevance of financial statement information, July (2004). Available at SSRN 585704, 2004

Xu, B., Magnan, M.L., \& Rrè, P.E. (2007). The stock market valuation of R\&D information in biotech firms. Contemporary Accounting Research, 24(4), 1291-1318.

Yoon, B., \& Chung, Y. (2018). The effects of corporate social responsibility on firm performance: A stakeholder approach. Journal of Hospitality and Tourism Management, 37, 89-96.

Zainuldin, H. M., \& Lui, T. K. (2018). Earnings management in financial institutions: A comparative study of Islamic banks \& conventional banks in emerging markets. Pacific- Basin Finance Journal, (2018). doi.org/10.1016/j.pacfin.2018.07.005. 
APPENDIX A

CSR Disclosure Categories Index (Total Disclosure Items = 84)

\begin{tabular}{|c|c|c|c|}
\hline SL & CSR Disclosure Index & Sources Using Similar Disclosure Categories & $\begin{array}{l}\text { Aspects/Sub-categories } \\
\text { (from GRI \& prior studies) }\end{array}$ \\
\hline & \multicolumn{3}{|l|}{ 1st Dimension: Economic Disclosures (EcD) } \\
\hline 1 & Capital structure; & Sobhani et al., 2012 & Economic Disclosure \\
\hline 2 & Dividend policy; & Sobhani et al., 2012 & Economic Disclosure \\
\hline 3 & Contribution to national exchequer & Ullah et al., 2015 & $\begin{array}{l}\text { Economic } \\
\text { Performance (GRI) }\end{array}$ \\
\hline 4 & Information concerning remittance collection & Sobhani et al., 2012 & Economic Disclosure \\
\hline 5 & Comparative financial growth with previous years & Sobhani et al., 2012 & Economic Disclosure \\
\hline 6 & Review of corporate financial performance & Sobhani et al., 2012 & Economic Disclosure \\
\hline 7 & Infrastructural \& institutional development & GRI, 2013 & $\begin{array}{l}\text { Economic Performance } \\
\text { (GRI) }\end{array}$ \\
\hline 8 & State of domestic economy & GRI, 2013; Rahman et al., 2019; Rahman et al., 2020 & $\begin{array}{l}\text { Economic } \\
\text { Performance (GRI) }\end{array}$ \\
\hline 9 & Impact of global economy & GRI, 2013; Rahman et al., 2019; Rahman et al., 2020 & Economic Performance (GRI) \\
\hline \multirow[t]{3}{*}{10} & Other economic disclosure & GRI, 2013 & Economic Performance (GRI) \\
\hline & \multicolumn{3}{|l|}{ 2nd Dimension: Environmental Disclosures (EnD) } \\
\hline & \multicolumn{3}{|l|}{ 2.1 Disclosure of Energy Consumptions \& Savings } \\
\hline 11 & Energy saving policies & GRI, 2013; Rahman et al., 2019; Rahman et al., 2020 & Biodiversity (GRI) \\
\hline 12 & Investing in renewable energy & GRI, 2013; Rahman et al., 2019; Rahman et al., 2020 & Energy (GRI) \\
\hline 13 & $\begin{array}{l}\text { Information concerning energy consumption (Gas/Fuel/ } \\
\text { Electricity) }\end{array}$ & GRI, 2013 & Energy (GRI) \\
\hline
\end{tabular}




\begin{tabular}{|c|c|c|c|}
\hline 14 & $\begin{array}{l}\text { Direct Greenhouse Gas (GHG) Emissions, e.g. Include travel on behalf } \\
\text { of the company or use of the company fleet; \& Include the use of courier services. }\end{array}$ & GRI, 2013 & Emissions (GRI) \\
\hline 15 & Energy Indirect Greenhouse Gas (GHG) Emissions & GRI, 2013 & Emissions (GRI) \\
\hline 16 & Corporate environmental policies & $\begin{array}{l}\text { Belal \& Abdelsalam, 2015; Ullah } \\
\text { et al., } 2015\end{array}$ & Environment \\
\hline 18 & Initiatives for water supply \& sanitations; & Sobhani et al., 2012 & Environment \\
\hline 19 & Environmental financing such as 'ecological credits' & GRI, 2013 & Environment \\
\hline 20 & Tree plantation programmes & Ullah et al., 2015 & Effluents \& waste (GRI) \\
\hline 21 & Undertaking beautification programmes (Road \& city) & Ullah et al., 2015 & Environment \\
\hline 22 & Issues concerning climate change & $\begin{array}{l}\text { GRI, 2013; Rahman et al., 2019; } \\
\text { Rahman et al., } 2020\end{array}$ & Environment \\
\hline 2 & Solar panel distribution to the poor people $\&$ use of Solar panel in office & Ullah et al., 2015 & Environment \\
\hline 25 & Providing online information to reduce pollution & Ullah et al., 2015 & Environment \\
\hline 26 & Climate change risk fund & Ullah et al., 2015 & Environment \\
\hline 27 & $\begin{array}{l}\text { Certified environmental management system/ Environmental } \\
\text { certification (e.g. ISO-14001) }\end{array}$ & GRI, 2013 & Environment \\
\hline 28 & $\begin{array}{l}\text { Promoting environmental awareness to the community through } \\
\text { promotional tools inclusive financing for productive SME, agriculture \& } \\
\text { environmentally beneficial project }\end{array}$ & Khan et al., 2010 & Environment \\
\hline & \multicolumn{3}{|l|}{ 3rd Dimension: Social Disclosure (SD) } \\
\hline & \multicolumn{3}{|l|}{ 3.1 Disclosure of Contribution to Community Investment } \\
\hline 25 & Importance of community development & GRI, 2013 & Local Communities (GRI) \\
\hline
\end{tabular}




\begin{tabular}{|c|c|c|c|}
\hline 31 & Rural development programmes; & $\begin{array}{l}\text { Ullah et al., 2015; Sobhani et al., } \\
2012\end{array}$ & $\begin{array}{l}\text { Community } \\
\text { Investment/Involvement }\end{array}$ \\
\hline 32 & Credit facilities for women entrepreneurs or initiative to empowering woman; & $\begin{array}{l}\text { Sobhani et al., 2012; Ullah et al., } \\
2015\end{array}$ & $\begin{array}{l}\text { Community Investment/ } \\
\text { Involvement }\end{array}$ \\
\hline 33 & Helping disadvantaged people; & Sobhani et al., 2012 & $\begin{array}{l}\text { Community Investment/ } \\
\text { Involvement }\end{array}$ \\
\hline 34 & $\begin{array}{l}\text { Aiding victims of natural disasters (Such as flood \& tornado, } 1 \& \text { slides, } \\
\text { river erosions etc.) }\end{array}$ & $\begin{array}{l}\text { Khan et al., 2010; Sobhani } \text { et al., } \\
2012\end{array}$ & $\begin{array}{l}\text { Community } \\
\text { Investment/Involvement }\end{array}$ \\
\hline 35 & Distribution of worm cloths among the cold-affected people & Khan et al., 2010 & $\begin{array}{l}\text { Community } \\
\text { Investment/Involvement }\end{array}$ \\
\hline 36 & Observation of various national ceremonies; & Belal et al., 2009 & $\begin{array}{l}\text { Community Investment/ } \\
\text { Involvement }\end{array}$ \\
\hline 37 & Support to the foreign victims; & Ullah et al., 2015 & $\begin{array}{l}\text { Community Investment/ } \\
\text { Involvement }\end{array}$ \\
\hline 38 & $\begin{array}{l}\text { Birth control products with a view to solving the population problem \& } \\
\text { to conduct camps for voluntary sterilization }\end{array}$ & Ullah et al., 2015 & $\begin{array}{l}\text { Community } \\
\text { Investment/Involvement }\end{array}$ \\
\hline 39 & $\begin{array}{l}\text { Supporting the development of local industries or community (social } \\
\text { awareness) programs \& activities; }\end{array}$ & Ullah et al., 2015 & $\begin{array}{l}\text { Community } \\
\text { Investment/Involvement }\end{array}$ \\
\hline 40 & Heritage preservation & Ullah et al., 2015 & $\begin{array}{l}\text { Community Investment/ } \\
\text { Involvement }\end{array}$ \\
\hline \multirow[t]{2}{*}{41} & Special care for NRBs (Non-Resident Bangladeshi’s) & Ullah et al., 2015 & $\begin{array}{l}\text { Community Investment/ } \\
\text { Involvement }\end{array}$ \\
\hline & 3.2 Disclosure of Islamic Commitments, Zakah \& Quard Hassan & & \\
\hline 42 & Policy for dealing with insolvent clients; & $\begin{array}{l}\text { Belal et al., 2015; Haniffa et al., } \\
2007\end{array}$ & Islamic Commitments \\
\hline 43 & Conferences on Islamic economics; & $\begin{array}{l}\text { Belal et al., 2015; Haniffa et al., } \\
2007\end{array}$ & Islamic Commitments \\
\hline 44 & Commitments in operating within Shari'ah principles/ideals & $\begin{array}{l}\text { Belal et al., 2015; Haniffa et al., } \\
2007\end{array}$ & Islamic Commitments \\
\hline 45 & Commitments in providing returns within Shari'ah principles & $\begin{array}{l}\text { Belal et al., 2015; Haniffa et al., } \\
2007\end{array}$ & Islamic Commitments \\
\hline
\end{tabular}


3.3 Disclosure of contribution to Health:

\begin{tabular}{|c|c|c|c|}
\hline 46 & Establishment of health care center for rural people for free medical services & Khan et al., 2010 & Health \\
\hline 47 & $\begin{array}{l}\text { Donation of cash money for construction of hosital/clinics/medical college } \\
\text { etc. (e.g. cancer hospital; eyes hospital) }\end{array}$ & Khan et al., 2010 & Health \\
\hline 48 & $\begin{array}{l}\text { Provide procurement facilities of any medicine/medical equipement/materials } \\
\text { (e.g. operation theater for kidney hospital; } \\
\text { ambulance; equipement for poor Thalassemia patients etc. ) }\end{array}$ & Khan et al., 2010 & Health \\
\hline 49 & Health campaign (free medical camp/clinic) & Ullah et al., 2015 & Health \\
\hline 50 & Sponsoring in medical research & Ullah et al., 2015 & Health \\
\hline \multirow[t]{2}{*}{51} & $\begin{array}{l}\text { Sponsoring Seminar on health issues \& awareness program (e.g. HIV/AIDS } \\
\text { assistance programme) }\end{array}$ & $\begin{array}{l}\text { Ullah et al., 2015; Khan et al., } \\
2010\end{array}$ & Health \\
\hline & \multicolumn{3}{|l|}{ 3.4 Disclosure of contribution to Education \& others: } \\
\hline 52 & $\begin{array}{l}\text { Establishment educational institutions (Schools, College, Madrasha, Libraries; } \\
\text { Laboratory); }\end{array}$ & $\begin{array}{l}\text { Ullah et al., 2015; Belal et al., } \\
2015\end{array}$ & Education \\
\hline 53 & $\begin{array}{l}\text { Sponsoring science fair, math olympiad, Quiz competition, art exhibition etc. } \\
\text { (local \& international) }\end{array}$ & $\begin{array}{l}\text { Ullah et al., 2015; Belal et al., } \\
2015\end{array}$ & Education \\
\hline 54 & Funding scholarship program; & Ullah et al., 2015 & Education \\
\hline 55 & Patronizing general \& technical education; & Sobhani et al., 2012 & Education \\
\hline 56 & Donation to the universities for constructing research center; & Khan et al., 2010 & Education \\
\hline \multirow[t]{2}{*}{57} & Scholarships to the research students of different universities; & Khan et al., 2010 & Education \\
\hline & \multicolumn{3}{|l|}{ 3.5 Human Resource Development (HRD) Disclosure } \\
\hline 58 & Commitment to HR development & GRI, 2013 & Training \& Education (GRI) \\
\hline 59 & Employee compensation, welfare or donation & $\begin{array}{l}\text { GRI, 2013; Rahman et al., } \\
\text { 2019; Rahman } \text { et al., } 2020\end{array}$ & $\begin{array}{l}\text { Economic } \\
\text { Performance (GRI) }\end{array}$ \\
\hline 60 & Basic salary of men to women by employee category & $\begin{array}{l}\text { GRI, 2013; Rahman et al., } \\
\text { 2019; Rahman et al., } 2020\end{array}$ & $\begin{array}{l}\text { Equal Remuneration for } \\
\text { Woman \& Man (GRI) }\end{array}$ \\
\hline 61 & Information concerning provided fund & Sobhani et al., 2012 & Human Resource Development \\
\hline
\end{tabular}




\begin{tabular}{|c|c|c|c|}
\hline 62 & Male-female ratio in employment & GRI, 2013 & Employment (GRI) \\
\hline 63 & Executive profile/list of corporate senior officials & GRI, 2013 & Employment (GRI) \\
\hline 64 & $\begin{array}{l}\text { Training employees through in-house programmes (e.g. } \\
\text { leadership program; disability antidiscrimination program } \\
\text { or career development programs }\end{array}$ & $\begin{array}{l}\text { GRI, 2013; Rahman et al., 2019; Rahman et } \\
\text { al., } 2020\end{array}$ & Training \& Education (GRI) \\
\hline 65 & $\begin{array}{l}\text { Percentage of employees receiving regular performance \& } \\
\text { career development reviews }\end{array}$ & GRI, 2013 & Training \& Education (GRI) \\
\hline 66 & Information about trainers \& trainees & GRI, 2013 & Training \& Education (GRI) \\
\hline \multirow[t]{2}{*}{67} & Reward/ Promotion \& recognition for better performance; & $\begin{array}{l}\text { Sobhani et al., 2012; Ullah et al., 2015; Belal } \\
\text { et al., } 2015\end{array}$ & $\begin{array}{l}\text { Human } \\
\text { Development }\end{array}$ \\
\hline & \multicolumn{3}{|l|}{ 3.6 Human Rights Disclosure (HRD) } \\
\hline 68 & Healthy \& safe workplace for staff & GRI, 2013 & $\begin{array}{l}\text { Occupational } \\
\text { safety (GRI) }\end{array}$ \\
\hline 69 & loan facilities to the employees; & Sobhani et al., 2012 & Human Rights Disclosure \\
\hline 70 & Provisions for maternity \& paternity leaves & $\begin{array}{l}\text { GRI, 2013; Rahman et al., 2019; Rahman et } \\
\text { al., } 2020\end{array}$ & Employment (GRI) \\
\hline 71 & Disclosure on child labour or free from child labour & $\begin{array}{l}\text { GRI, 2013; Rahman et al., 2019; Rahman et } \\
\text { al., } 2020\end{array}$ & Child Labour (GRI) \\
\hline 72 & Equal opportunity; & Ullah et al., 2015 & Human Rights \\
\hline 73 & Employee benefits \& welfare; & Belal et al., 2015; Khan et al., 2010 & Employee information \\
\hline 74 & Managerial remuneration; & Muttakin et al., 2015 & Employee information \\
\hline 75 & Creating Job opportunities & $\begin{array}{l}\text { Ullah et al., 2015; Belal \& Abdelsalam, } \\
2015\end{array}$ & Employee information \\
\hline 76 & Increasing employees financial \& economic awareness; & Ullah et al., 2015 & Employee information \\
\hline & \multicolumn{3}{|l|}{ 3.7 Product \& Service Responsibility Disclosure } \\
\hline 77 & $\begin{array}{l}\text { Different types of products \& services (Glossary/definition } \\
\text { of products) }\end{array}$ & GRI, 2013 & $\begin{array}{l}\text { Product \& } \\
\text { labelling (GRI) }\end{array}$ \\
\hline
\end{tabular}




\begin{tabular}{|l|l|l|l|}
\hline 78 & Research \& development' for products \& services & GRI, 2013 & Customer Health \& Safety \\
\hline 79 & Good customer relation; & Ullah et al., 2015 & Consumer \\
\hline 80 & Complaints received \& resolution information & GRI (2013), Sobhani et al., 2012 & Customer Privacy (GRI) \\
\hline 81 & $\begin{array}{l}\text { Policy \& compliance mechanism for protecting financial privacy of } \\
\text { customers; }\end{array}$ & Ullah et al., 2015; Belal et al., 2015 & Consumer \\
\hline 82 & Service to disable clients; & Khan, et al., 2009 & $\begin{array}{l}\text { Product \& Service } \\
\text { Information }\end{array}$ \\
\hline 83 & Product \& consumer safety/ Fund security; & Ullah et al., 2015 & Consumer \\
\hline 84 & $\begin{array}{l}\text { Procedures for assessing \& screening environmental \& social risks } \\
\text { in business lines }\end{array}$ & $\begin{array}{l}\text { GRI, 2013; Rahman } \text { et al., 2019; Rahman } \\
\text { et al., 2020 }\end{array}$ & Product Portfolio (GRI) \\
\hline
\end{tabular}

Sources: Adapted from GRI, 2013; Sobhani et al., 2012; Ullah et al. (2015); Belal \& Abdelsalam (2015); Khan et al., 2010; Haniffa et al., 2007; Khan et al. 2009; Muttakin et al., 2015; Belal et al., 2009; Rahman et al., 2019; Rahman et al., 2020. 